\title{
Environmental Aspects of the Accelerated Urbanization in Sana'a, Yemen
}

\author{
Ahmed M. Alderwish ${ }^{\star}$ and Fayad A. Alderwish ${ }^{\star \star}$
}

${ }^{*}$ Department of Earth and Environmetal Science, Sana'a University, P.O.Box 11903, Sana'a, Yemen, Email: Alderwish@y.net.ye, ${ }^{* \star D}$ epartment of Architecture, Faculty of Engineering, Sana'a University, Yemen.

جوانب بيئية للتمدن المتسارع في صنعاء ، اليمن أحمد الارويش وفياض الدرويش

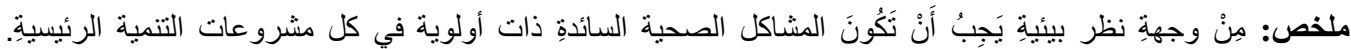

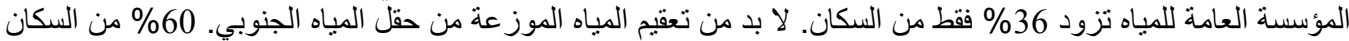

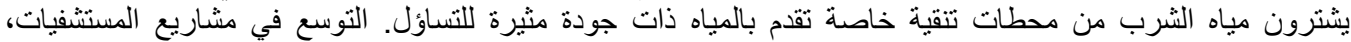

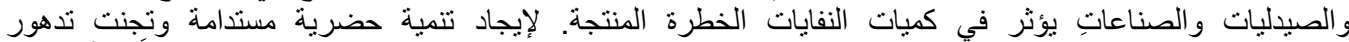

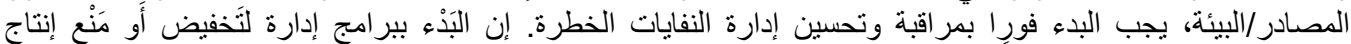

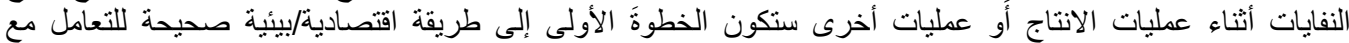

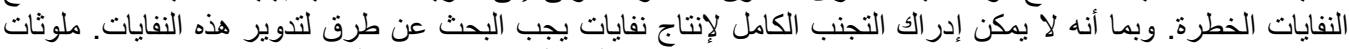

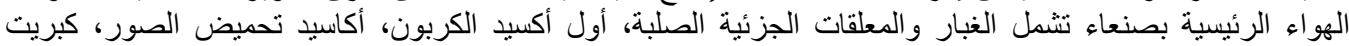

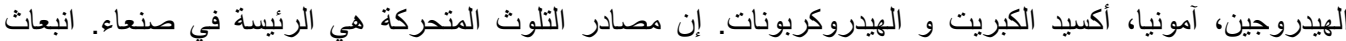

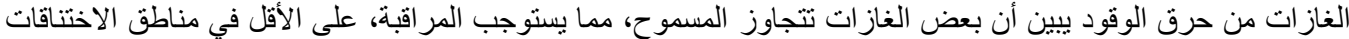

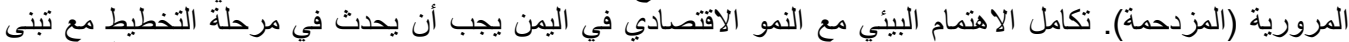

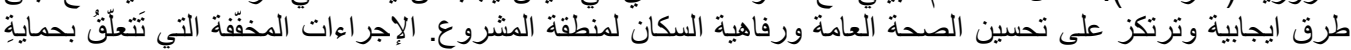

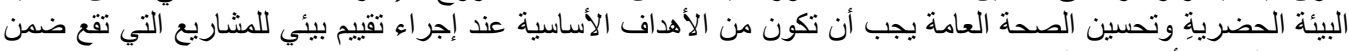
مناطق الحضر أو تؤثر على بيئتها.

ABSTRACT: From an environmental viewpoint, the prevailing health problems must be a "first priority" in all major development projects. Public water supply provides only $36 \%$ of domestic water. Disinfection of public water supply from the south well field is essential to avoid health problems. About $60 \%$ of the drinking water sold by 'hygienic' stations is of questionable quality. Expansion and upgrading in hospitals, pharmacies and industries (waste producers) will have an immediate impact on the amount of hazardous waste that will have to be disposed of. To achieve a sustainable urban development and to avoid environment/resources degradation, care should be taken now to monitor and improve handling and management of hazardous waste. Initiating management programs for reducing or preventing the generation of waste during production processes or other operations would 


\section{AHMED M. ALDERWISH and FAYAD A. ALDERWISH}

be the first step to an economically and environmentally sound way of dealing with hazardous wastes. As complete elimination cannot be realized, ways to recycle the wastes should be sought. Major air pollutants in Sana'a include dust and SPM, carbon monoxide, photochemical oxidants, hydrogen sulfide and ammonia, sulfur oxides and hydrocarbons. The main sources of pollution in the cities are the mobile sources. The emissions of gases from oil consumption are exceeding the permissible level and it is essential that the gases be monitored, at least in the congested areas of the cities. Integration of environmental concerns with economic growth in Yemen should occur at the planning stage, adopting a positive approach and focusing on improvement in the health and welfare of the residents of the program area. Mitigating measures relating to the protection of the urban environment and improving public health must be primary objectives of EIA investigation for any upgrading project within urban areas and any other projects impacting on an urban environment.

KEYWORDS: Urban; Development; Sana'a; Environment; Health; Water supply.

\section{Introduction}

$\mathbf{F}$ Tor many observers the greatest concern is surely the massive increase in the numbers of the urban poor. Available data suggest that in a large number of the world's poorest countries, the proportion of urban poor is increasing faster than the overall rate of urban population growth, ( UN-Habitat, 2004). An estimated 72 percent of the urban populations of Africa now live in slums, (UN-HABITAT, 2003). The proportion is 43 percent for Asia and the Pacific, 32 percent for Latin America, and 30 percent for the Middle East and Northern Africa (UN-Habitat, 1998). A long-standing urban bias in social infrastructure investments has contributed to the widely held belief in the development literature that living conditions must be far better in large cities than in smaller cities or towns. But with the locus of poverty moving to cities, the longassumed advantages enjoyed by residents of large cities have been called into question, (Brockerhoff and Brennan, 1998). In addition, the international debt crisis has hit many countries hard, and the implementation of structural adjustment programs in many developing countries has led to a retrenchment of government subsidies and social expenditures that has affected urban residents disproportionately (NRC, 2003). Cities throughout the world exhibit an incredible diversity of characteristics, economic structures, levels of infrastructure, historic origins, patterns of growth, and degrees of formal planning. Yet, many of the problems that they face are strikingly familiar.

The urban population explosion in Yemen has created major problems for government agencies responsible for providing adequate facilities to its citizens. As in other developing countries, urbanization in Yemen is so rapid that planners have little time to make provision for this phenomenal growth. Sana'a is one of the fastest growing cities in Yemen. Rapid industrialization, and consequent demographic changes, have created stress on civic amenities and outstripped the resources of the authorities to provide basic needs such as clean water, as well as posing major challenges for sustainable development.

To begin to deal with these challenges will, at a minimum, require accurate assessment of the present situation. This study assesses the current environmental aspects of basic service delivery in the city of Sana'a, assesses the environmental aspects and disease transmission associated with urban development, and discusses urban expansion, including industrial and hazardous waste, and air pollution. Natural environmental constraints together with degradation of land and ecosystems are outlined.

\section{Study Area and Methods}

The study is based on the available literature, discussions with concerned officials and observations. For 


\section{ENVIRONMENTAL ASPECTS OF THE ACCELERATED URBANIZATION}

the purpose of assessing the current environmental aspects of the Sana'a City, each component has been investigated using an appropriate approach based on the available data and information.

For domestic water supply in Sana'a, the public water supply system could not cover all of the urban population. Consequently, a private water supply sector developed to fill the gap between the quantity of water supplied by National Water and Sanitation Authority (NWSA) and the city demand. It has developed from a complementary activity into an important economic activity.

Previous studies conducted in Yemen (ACE, Burns \& McDonnell International, 1993; Haskoning, 1991), provide useful background information on the hazardous waste management. Several hazardous waste producers and the nature of their waste have been described, without, however, detailed quantitative information on many of the potential hazardous pollutants or the mitigation measures. Hazardous wastes being produced within Sana'a area include: waste oil produced by commerce and vehicle servicing, halogenated solvents produced from dry cleaning services, cyanides, from the production of polyurethane sponge, acids and alkalis from small laboratories within factories, batteries which are disposed of indiscriminately after use, and sludge from factories which is not dumped locally "near to factories" but probably goes to landfill sites, etc. There is no information on the composition or their quantities of any of these and hence it is difficult to assess how serious their environmental threat is. Nevertheless, pollution by hazardous chemicals is very harmful to humans and the environment, even at very low concentration. Moreover, these chemicals are very long-lived and very hard to clean up from the environment. For example, if a hazardous contaminant reaches groundwater it will move in the direction of groundwater flow in the shallow aquifer and probably be intercepted in some year's time in an area where groundwater is used.

To date, there are no monitoring stations for air quality in all of Yemen, consequently air pollutants and their sources have been identified indirectly. Emissions of gases were estimated analytically from oil consumption. Table 1 shows the consumption of petrol in Sana'a during 2010 and the corresponding emitted gases as well as the permissible level based on World Bank guidelines. Although these figures are only estimates from the sold oil, they indicate that for some gases the emission is exceeding the permissible level. There is no study in Yemen concerning health impacts of these gases. However, studies from other countries indicated that the presence of these gases at high concentration in air might cause several respiratory diseases and lung cancers.

Table 1. Quantities of Petrol Consumption and Emitted Gases in the Air of Sana'a in 2010

\begin{tabular}{|l|c|c|c|c|c|c|}
\hline \multicolumn{1}{|c|}{ Pollutant } & $\begin{array}{c}\text { Petrol } \\
\text { consumption } \\
\text { (liter) }\end{array}$ & NOx & Hydrocarbon & SPM & CO & Sox \\
\hline Emission (tones/year) & 935,832 & 17,138 & 19,993 & 5,090 & 171,561 & 2,214 \\
\hline $\begin{array}{l}\text { Approx. emission } \\
\text { microgram/m3/day }\end{array}$ & & 146 & 171 & 43 & 1,468 & 19 \\
\hline P.L. microgram/m3/day & & 150 & 160 & 50 & 30 & 150 \\
\hline
\end{tabular}

Source: modified EPA's reports.

The main constraint of the natural environment in Sana'a city is that it is surrounded by a mountainous area. Despite being very attractive scenically, the steep bare mountainsides coupled with intensive rainfall of short duration, causes occasional serious damage due to sediment-laden flooding. These special geographic features impose certain difficulties on the design, operation and maintenance of road, storm, and sewage drainage, and hence pose special environmental problems.

On the base of a Sana'a urban ecology study conducted in 1993, (Norra, 1995), the following areas have been identified as protection and/or ecological improvement areas: Wadi Al Salya, Hadda, Area east of Dar Salm, Wadi Shamlan, Wadi Dhar, Wadi Assir, Old City gardens, irrigation system water pools out of earth and 


\section{AHMED M. ALDERWISH and FAYAD A. ALDERWISH}

natural stones, and Samnah village. All these areas are of relative high biological richness except large areas of Wadi Al Syla. Nevertheless, Wadi Al Syla, as an abandoned area, has a high potential to improve the ecological situation in Sana'a. Trees are necessary in this area to improve the air quality. Nonetheless, forestation should not block the fresh wind lane of Wadi Al Syla by densely planted trees, as it provides fresh air to the entire city.

\section{Results and Discussion}

\subsection{Aspects of Water Supply}

The large increases in the numbers of urban residents in the developing world imply that municipal authorities responsible for these sectors face very serious challenges. In many cities, the scarcity of public water supplies forces many low-income urban residents to use other water sources such as private water vendors who charge many times more than the local public rate. Consequently, people in slums often must pay much more for lower quality water than other urban residents (Satterthwaite, 1997).

The supply of water in Sana'a relies fully on the local groundwater resources and all the water comes from three well fields called Western, Eastern and Southern well fields. For the southern well fields most of the water is pumped directly into the distribution network, i.e. without chlorination. An important health implication for pumping water without disinfection has been realized from the incorrect conclusion drawn by (Dar Al Handasah (1999), when they attempted to relate the source of families' water supply or their method of sewage disposal to the incidence of diarrhea, intestinal infections, and skin diseases over some areas in Sana'a. It has been found that much better and clearer relationships do exist between the incidence of diarrhea, intestinal infections, and skin diseases, and those areas receiving a public water supply that has not been chlorinated. Although the distribution system is equipped with three reservoirs constructed as balancing reservoirs, due to the present imbalance between demand and supply the reservoirs cannot be filled (Figure 1). Consequently, this has led people to install tanks (below ground surface) to receive and store water. These tanks are not clean and usually have iron sedimentation at the bottom. Further, in some of these tanks there are cockroaches, dead mice, algae, etc.

Private water is provided via numerous small local distribution networks and a large fleet of water tankers (small trucks that can carry about $4 \mathrm{~m}^{3}$ ). It is estimated that the private sector provides about $64 \%$ of the water used for domestic purposes in Sana'a, (JICA, 2007). So far, no comprehensive study of the private water supply sector had been done.

The quality of the water provided by NWSA complies with WHO standards for safe drinking water. It is doubtful, though, that the quality at the tap can be considered safe. The reason is that the distribution network is operated on a rotational basis and consequently a deterioration of the water quality in the system is most probable. Al-Hamdi (1994) identifies direct microbiological contamination of the distribution network caused by the temporary depressurization of, and subsequent infiltration of domestic sewage into, the transport pipelines for drinking water. No coliform bacteria were detected in any of the drinking water samples. This was attributed to the retaining of bacteria by soil particles. Using data from NWSA files provides a picture that is far from complete because monitoring is not done regularly or comprehensively. There are no NWSA standard requirements for the monitoring of public supply water. It would be a valuable step forward if some moves in this direction could be made as new public supplies as well as the numbers of people served are increasing in number. More investment in laboratory facilities is probably required. The ideal water quality assessment would be based upon a comprehensive set of samples simultaneously and correctly taken across the city, and analyzed by the same laboratory by the same analyst to avoid discrepancies.

Water samples analyzed from private wells (Alderwish and Dottridge, 1999; Ruseman,1996), indicate that deteriorating water quality exists over a large part of Sana'a city (old city, Al-Qa'a, and Al-Hasaba) as reflected by the high values of EC (2,000 to 4,000 mS/cm). Cesspits that drain domestic wastewater to the shallow groundwater aquifer microbiologically pollute groundwater sampled from the Quaternary loose deposits. Depending on the subsoil conditions, the safe distance between the bottom of a cesspit and the intake level of a well should, for bacteria elimination, be between $75 \mathrm{~m}$ and $285 \mathrm{~m}$. Investigations carried out by 


\section{ENVIRONMENTAL ASPECTS OF THE ACCELERATED URBANIZATION}

SAWAS technical team on 1995 revealed that distances as short as $7 \mathrm{~m}$ frequently occur, (Foppen et al. 1996). As a consequence about $85 \%$ of the private wells used for domestic water supplies provide "un-safe" (from a microbiological point of view) water for drinking purposes according to WHO standards.

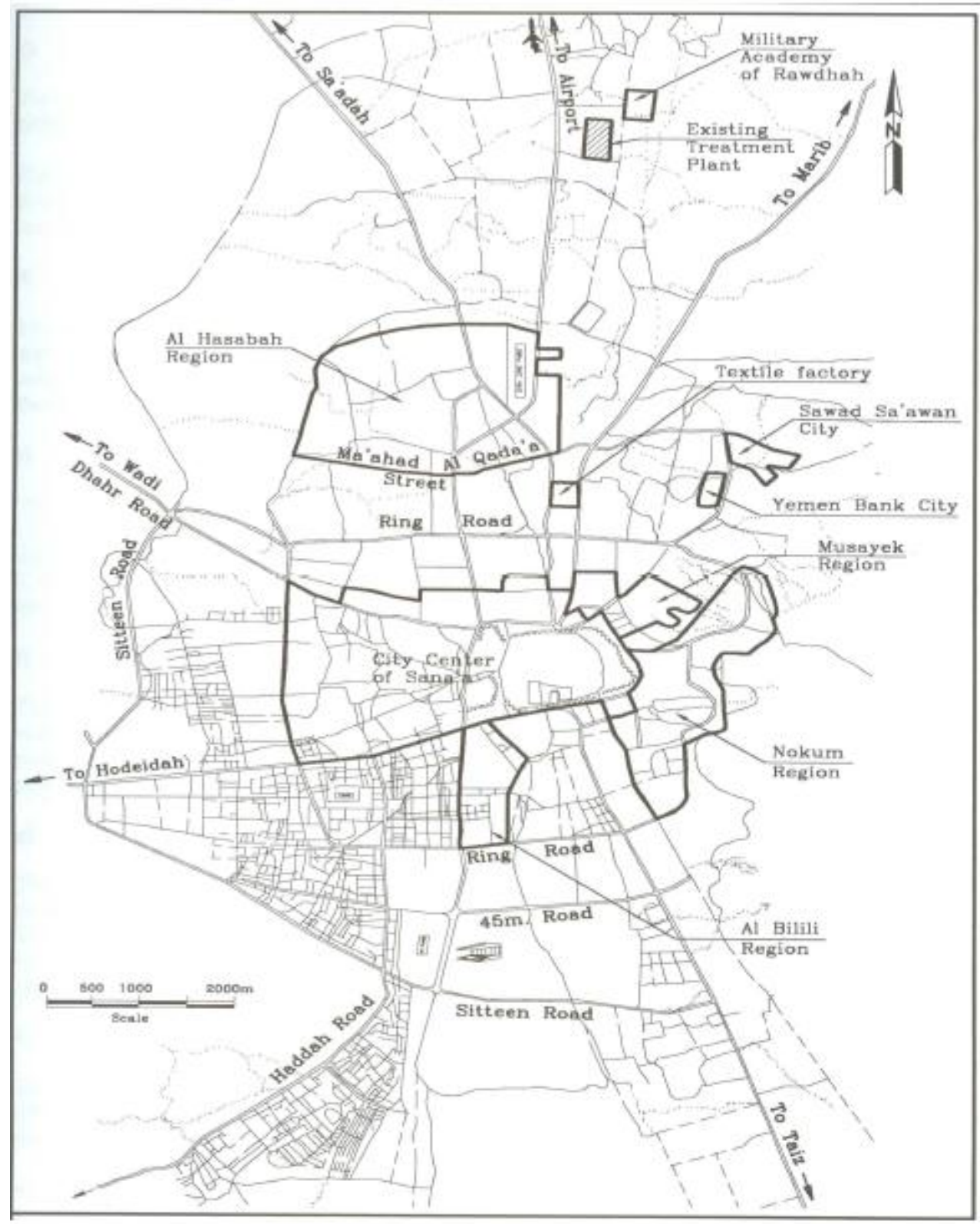

Figure 1. Public water supply coverage, (Dar Al-Handasah 1999).

Several private vendors are providing "hygienic" drinking water for about $60 \%$ of the urban population. It is being provided through plastic containers of 10 and 20 liters capacity. Stations are equipped with various 


\section{AHMED M. ALDERWISH and FAYAD A. ALDERWISH}

water treatment systems, which can include sand filter, chlorinated vessel, reverse osmosis, etc. The quality of the water produced by these stations is very questionable. In 1997, a team from NWSA visited 14 of these stations and concluded that most of the stations are simply cheating the public, and the following was observed: chlorination is not done or it is done improperly, most of purification systems' components are not working (left as decoration), ground and pipes to fill containers are not clean, some stations have more than one raw water source, there is no expert technician in any of these stations to follow up the efficiency of the station and the quality of water produced; and finally, to date there is no comprehensive investigation nor regular and proper monitoring for these stations by any public authority.

As is the case in the water supply distribution network, sewerage systems are more available to upper- and middle-class neighborhoods than they are in poorer neighborhoods, particularly unregulated neighborhoods on the urban periphery.

\subsection{Industrial and Hazardous Waste}

Improving public sanitation is another major urban environmental challenge that needs to be immediately addressed in virtually all cities in the developing world, Cohen (2006). Failure to collect garbage as well as inadequate waste management and recycling policies and practices mean that cities are being inundated by their own waste. Similar to the situation of African cities, waste management has been described as 'a monster that has aborted most efforts made by city authorities, state and federal governments and professionals alike', (Onibokun, 1999). Industrial and hazardous waste can impact the environment in three principle forms, air pollution, water pollution and solid wastes.

Although in Sana'a there is some kind of zoning, it seems that it either came too late or it is not strictly enforced as reflected in the presence of industrial sites in the middle of the residential areas and vice-versa. An old large industry, Yemen Textile Corporation Factory was established at the boundary of what was then the city. Now however it is in the middle of the city. Other more recent smaller and medium-scale industries (e.g., small food and soft drink manufacturers) exist within the city. It is understood that there is a plan to move out these small-medium industries from the city center. In the following, major hazardous waste producers in Sana'a together with the major media with which the contaminants are associated are briefly described.

Hospital Waste (hazardous and non-hazardous) is generally stored in drums, collected by the municipalities and dumped somewhere on landfills. Although public hospitals have their own furnaces to incinerate the waste, only the TB clinic in Sana'a is using its facilities. The number of hospital beds in Sana'a city in 2010 is estimated as 3,146. Assuming a similar average solid waste production of $635 \mathrm{~kg} /$ year for every hospital bed, (Haskoning, 1991), 2,000 tons/year of hospital waste is generated in Sana'a. These figures are excluding wastes produced by private clinics and private hospitals. It should be noted that, if separation of hazardous waste (pathological chemicals and radioactive waste) from the non-hazardous waste (domestic waste) is carried out at hospitals, the generated hazardous waste quantities from hospitals can be reduced by $90 \%$. The chemical waste from laboratories connected to hospitals, e.g., X-ray departments, blood banks etc. are disposed of into the sewerage system, (about 10 tons/year in Sana'a). Among these chemicals, there is cyanide, chromate, phenol and mercury. All are very toxic chemicals. Chemicals disposed of in larger quantities are acids, alkalis and methyl blue. Major pollution control problems associated with hospitals waste handling are: the potential spread of infections via contamination of workers using poor procedures to handle hospital wastes, and potential contamination of soils, surface waters, and groundwater due to inadequate storage and most probably inadequate disposal of hospital wastes.

The amount of pharmaceutical waste is difficult to assess due to the existence of illegally (uncounted) imported medicines. In Sana'a there are 385 pharmacy shops. Some of the illegal operators indicate an average annual generation of $20 \mathrm{~kg} /$ year of expired medications. An estimate of the amount of pharmaceutical waste in Sana'a indicates that about 53 tons/year is generated including that from suppliers of medicines and the pharmaceutical industry (YEDCO). Major pollution control problems associated with pharmaceutical industries 


\section{ENVIRONMENTAL ASPECTS OF THE ACCELERATED URBANIZATION}

are potential soil and groundwater contamination brought on by disposal of expired medicines or pharmaceutical process residuals; human health problems may result from ingestion of expired medicines.

Textile Factory Waste is one of the worst possible, with hazardous pollutants released to the urban air, water and soil environments. The factory produces 15 million yards of finished textiles annually and produces several thousand cubic meters of wastewater believed to be contaminated with a range of hazardous polyarmotic hydrocarbons, cyanide, heavy metals and paint solvents, together with mineral oil. This mixture is collected in three open drains and, after cursory settlement in four lagoons, is discharged at a point 400 meters north of the factory into a dry stream channel (Wadi Al Syla). Some farmers use this water for irrigation, (Al Eryani et al. 1991). Major pollution control problems associated with textile factories besides their hazardous chemicals is the improper waste water management, and the possibility of emitting volatile organic compounds (VOCs) as air emissions. The Yemen Textile Corporation Factory and its environs need urgent attention with respect to its environmental acceptability and immediate action could be taken by installing properly designed and managed treatment plant to remove the hazardous chemicals before release from the factory.

Photographic waste includes photo laboratories' chemicals that are used to develop films and print photos (mainly solvents, silver and acids). The total number of photo laboratories is still limited, but is growing. In Sana'a there are 18 labs. The average use of chemicals in labs is 4,000 liter/year, (Haskoning, 1991). The total use of chemicals in Sana'a is thus estimated as 81,000 liter/year. The chemicals are, without exception disposed into the sewerage system. The major pollution control problems associated with the photographic, printing and publishing industries are: potential contamination from discharge of untreated wastewater containing printing inks, solvents, silver, and acids, and air emissions of volatile organic compounds, dependent on the types and quantity of ink used by the industry.

There are numerous petrol and diesel filling stations existing in Sana'a. Although the possibility of leakage of new tanks is small, they may cause environmental risk in the urban areas where slow, longterm leakage of fuel from buried tanks, sufficient to contaminate groundwater to the extent of only $0.1 \mathrm{mg} / \mathrm{l}$, can render the resource unusable for a long time after the leak has been stopped, (Edworthy, 1991). People working in these gas stations are unaware of the risk of smoking while filling gas into cars, which indicate improper management. There are no extinguishers in many of these stations. Major oil storage tanks, especially where they are located over an aquifer, or adjacent to public water supply facilities should be surrounded by a fuel-tight retaining wall or bund, impounding sufficient capacity to hold the contents of the tank in the event of spillage. The floor of the areas should also be sealed to prevent infiltration of oil.

\subsection{Air Pollution}

Congestion in many large cities can also be extremely severe and air pollution is now a serious environmental concern in many cities (Cohen, 2006). Concentrations of carbon monoxide, lead, and suspended particulate matter in many large cities greatly exceed World Health Organization guidelines. Major air pollutants in Sana'a include dust and suspended particles, (solid particulate matters (SPM)), carbon monoxide, photochemical oxidant, hydrogen sulfide and ammonia, sulfur oxides, and hydrocarbons. Several have concentrations exceeding World Health Organization guidelines. Among the greatest environmental health concerns are exposure to fine particulate matter and to lead which contributes to learning disability in young children.

\section{Emissions from Power Plants}

Electricity is supplied by three major thermal power plants located in coastal areas. These plants supply a total of 435 MW electricity distributed mainly through a national grid network. In Sana'a there is a standby station that produces $50 \mathrm{MW}$ of electricity. Only for Dahaban electrical station, located $10 \mathrm{~km}$ northwest of Sana'a city center, has an EIA been undertaken recently, (Carl Bro international, 1998). The study showed that the emission concentration contribution of $\mathrm{NO}_{2}, \mathrm{SO}_{2}$ and particles from the station are within the permissible levels, 136, 84, and 20 microgram per cubic meter, respectively. 


\section{AHMED M. ALDERWISH and FAYAD A. ALDERWISH}

\section{Sources of Solid Particulate Matter}

Naturally, the central highland of Yemen (Sana'a) receives in average 10 dust storms per year, and 100 days of the year are classified as dusty to hazy. The landscape surrounding the cities under consideration are almost devoid of plant cover and consequently rain and wind erosion facilitates the local suspension of solid particulate matters (SPM) in the city's atmosphere. In Sana'a, the concentration of SPM in the air, is increased due to the presence of numerous stone quarries and brick kilns at the city limits. The concentration of SPM is further aggravated by vehicle traffic using the unpaved roads within the city. The main constituents of SPM emitted from vehicles are soot, lead, and heavy metals such as $\mathrm{V}, \mathrm{Cr}$, and $\mathrm{Ni}$ that are present in the fuel. The estimated production of particulate emission from the use of fuel (benzene and diesel) sold in 2010 in Sana'a corresponds to 5,090.5 tons/yr. It is expected that the concentration of lead in congested parts of the city would be in the range that requires monitoring. The concentration of SPM can be noticed visually through the building up of dust and haze during the day which reaches high concentrations during the afternoon when not washed out by afternoon rains during the rainy seasons.

\section{Carbon Monoxide Emissions}

In general, as heavy vehicle traffic is concentrated in the center of the city, the estimated amount of carbon monoxide emission from fuel is 171,561 tons/year. This estimate, as with the case of SPM is believed to be quite conservative since the majority of motor vehicles are old models and badly in need of maintenance. Hence, concentration of carbon monoxide in the congested parts of the cities would be in a range that requires monitoring.

\section{Photochemical Oxidants}

The emission of hydrocarbons and nitrogen oxides, together combined with long periods of sunshine and relatively calm winds, will facilitate the local formation of photochemical oxidants as a secondary pollutant, i.e., ozone, and hence the concentrations of these oxidants warrant observation (Table 1).

\section{Hydrogen Sulfide and Ammonia}

The concentration of hydrogen sulfide and ammonia should be monitored in the northern section of the Sana'a city. The source of these gases is the over loaded waste treatment plant located in the north of the city. The noxious odor of these gases is intensified during calm nights in the vicinity of the plant, or spread over a large part of the northern part of Sana'a city as the prevalent wind in Sana'a (Civil Aviation Meteorological Authority, CAMA) is the north- northeastern wind.

\section{Sulfur Oxides}

The main sources of the sulfur oxides in Yemen result from combustion of fuels that contain sulfur, and production and use of sulfuric acid. The estimated amount of sulfur oxides from the combustion of fuel does not exceed 2,214 tons/year. Heavy fuel oil does contain higher concentrations of sulfur. Nevertheless, it is not expected that sulfur oxide concentration will exceed international limits in the near future.

\section{Hydrocarbons}

Hydrocarbons play an important role in the formation of photochemical oxidants. The major sources of these pollutants at the present time arise from motor vehicle exhaust and evaporation. The estimated amount of this pollutant in Sana'a from fuel driven motor vehicles is 19,993 tons/year. Again this estimation is believed to be conservative due to the abnormal smoke and fumes emitted from car exhaust throughout these cities. Using the US EPA air pollution emission factor, it is estimated that the amount evaporated from transporting and dispensing this fuel will add about 44,700 tons annually to the air environment of Sana'a.

\section{Volatile Organic Compounds (VOCs)}

VOCs generators are mainly the textile industries, the printing and publishing industry (dependent on the types and quantity of ink used by the industry), and the petrochemical industry which also emits air toxins. 


\section{ENVIRONMENTAL ASPECTS OF THE ACCELERATED URBANIZATION}

A popular response to urban transportation congestion problems has been government investment in large-scale public transportation systems such as underground or overland metro systems. Less attention has been devoted to expanding and improving public bus networks, which tend to be overcrowded and poorly maintained. In many cities, private mini-bus locals have filled a hole in the market by providing low-cost urban transportation where standard bus routes have proved insufficient.

\subsection{Natural Constraints and Degradation of Ecosystems}

Sana'a basin $\left(3,200 \mathrm{~km}^{2}\right)$ is an inter-montane plain located in the central Yemen Highlands. Sana'a city stands on southern part of the Sana'a plain with elevation of about 2,200 m.a.s.l. and surrounded to the west, south and east by mountains rising to about 3,000 m.a.s.l (Figure 2). The vegetation in the urban area was cut by man to build, or as firewood and as rangeland for livestock. Virtually no places remain where man has not influenced the vegetation; the vegetation that is found currently is not "natural." With respect to the fauna in Sana'a cities only a fragmented and incomplete picture can be presented, because very little information on the subject is available for these areas. In conclusion it can be stated that very little is known on flora and fauna of Sana'a.

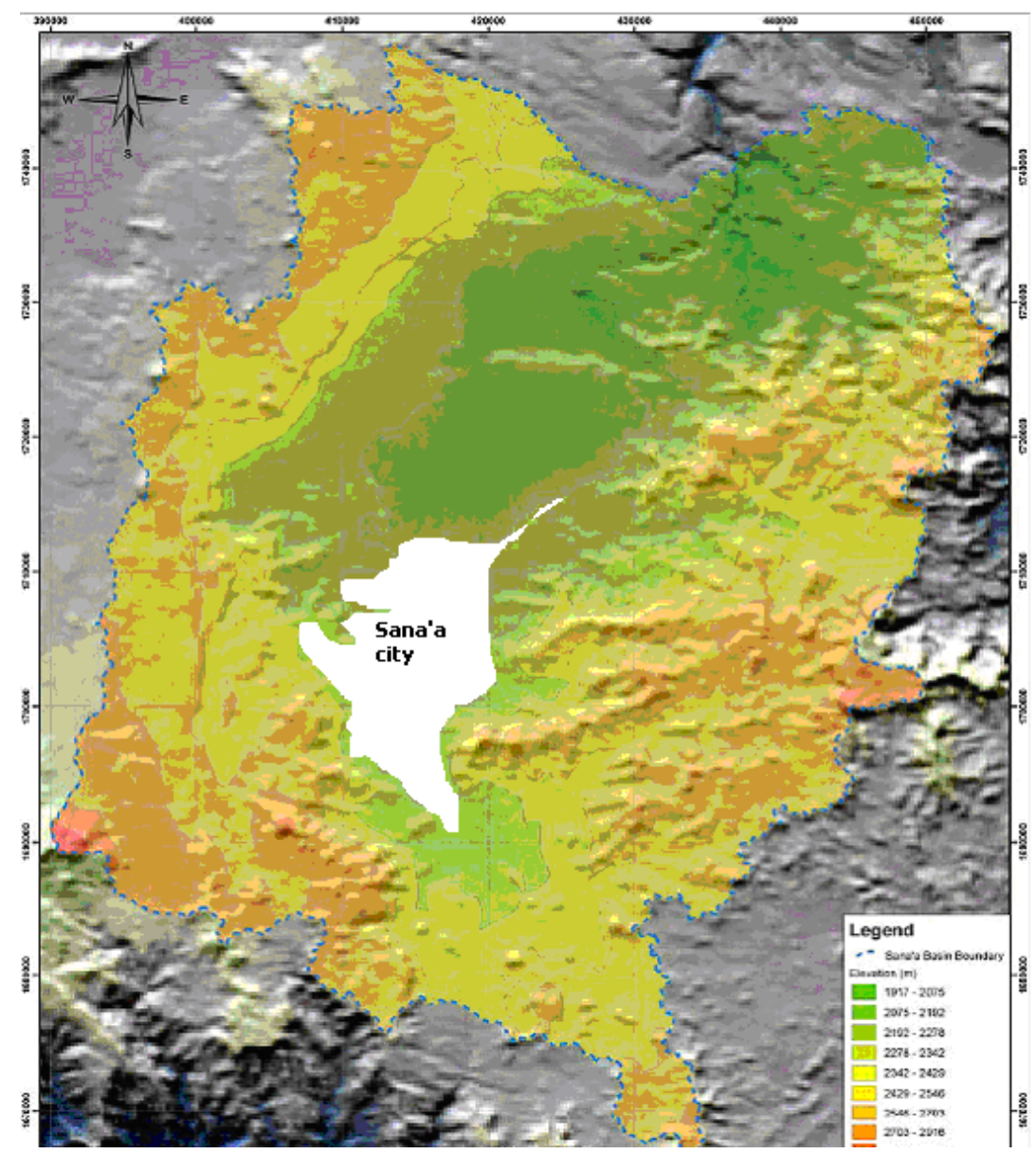

Figure 2. Elevation Map for Sana'a Basin indicating the basin digital elevation model. 


\section{AHMED M. ALDERWISH and FAYAD A. ALDERWISH}

\section{Urbanization Trends}

Before 1980, the built-up area of Sana'a city was virtually confined within the inner Ring Road. At present, the urban area covers about $132 \mathrm{Km}^{2}$, almost the total area with the Outer Ring Road (Alstaeen Street), and two important new urbanizations towards the south (the Hadda area). The city must extend to the south because in the north, the international airport, the wastewater treatment plant and important agricultural land all block the city's development (Figure 3). There are several ongoing urban development problems that may cause ecological problems now or in the future: the extension of free areas (future built-up areas)/planning of neighborhoods, the uncontrolled housing around Sana'a and along Wadi Al Syla, the road construction in Wadi Al Syla between Marib Road and Airport road, the $60 \mathrm{~m}$ road between the Medical faculty and the Libyan housing project, the endangering of the tree covered areas around Hadda by housing, and the increase of squatter areas.

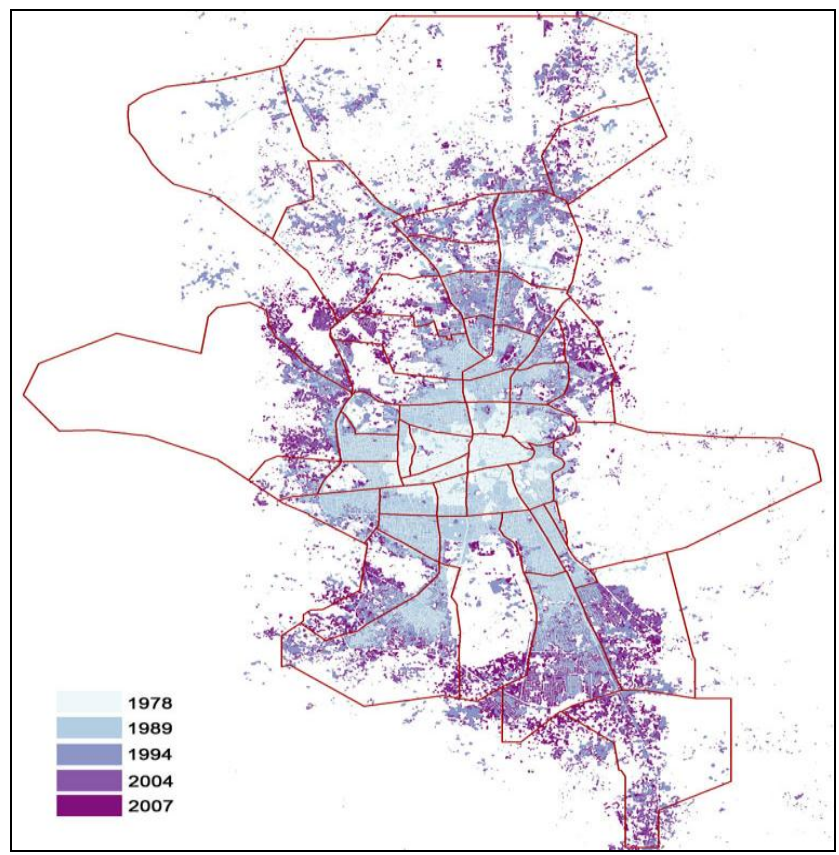

Figure 3. Analysis of city growth of Sana'a City/ Yemen during the last 30 years (Zeug et al. 2008).

The urban population and the larger merchants form a group of resource users. They look upon the exploitation of groundwater resources and agro industry as investment opportunities. They are no longer closely attached to the land nor do they bear a responsibility towards the other urban people. They have greatly stimulated the introduction of new technologies in Yemen, but they have not succeeded in providing a framework for a sustainable profit on their investments. Implementing decentralization would probably diminish part of this negative attitude. Also it is expected that decentralization of basic services would improve the environmental aspects of these services. For example, if revenue is kept at the branch, instead of sent to the central office, the branch would be able to improve its service by using the surplus of this revenue.

\section{Preservation of Natural Areas in Sana'a}

The area near Dar Salm, in the southeast of Sana'a is covered by many trees, mainly Acacia nilotica and Schinus molle as well as Opuntia ficus indica. A lot of old stone walls can be found in this area. These stone 


\section{ENVIRONMENTAL ASPECTS OF THE ACCELERATED URBANIZATION}

walls subdivide the whole area into small garden-like sites. The whole area shows no recent maintenance or use except signs of grazing and recreation. This spot is part of the area between the Taiz road and the Kohlan roads, which might be surfaced in future. Therefore the high development pressure of Sana'a will endanger this site. It has to be worked out together with the owners and the residents of Dar Salm how this area can be preserved asa natural and probably, cultural, monument.

\section{Conclusion}

Like other large cities in developing countries, impact congestion is very real and is greatly diminishing the quality of life in Sana'a City.

The prevalence of private water vendors highlights the high and growing demand for water that is not currently being met by the municipalities, and the trend for the immediate future appears unchanged. Questions about water quality, both public and private, and the adverse health effects are cause for serious concern. The immediate introduction of standards for monitoring the quality of public supply of water is a priority. Given the adverse economic effect on the poor due to the reliance on private distributors, it is suggested that a comprehensive study of the private water supply sector in the city be undertaken. Priority should be given to remedial action programs focusing on community health education, directed at women and children, regarding safe water-handling practices as well as sanitation and hygiene.

Investigations provide evidence that the present hazardous solid and liquid waste disposal techniques jeopardize the urban environment, public health and quality of groundwater below cities. Consequently, to achieve a sustainable urban development, care should be taken now to monitor and improve handling and management of hazardous waste. EIAs should be conducted for the establishment of all new industry regardless of its scale. Initiating management programs for reducing or preventing the generation of waste during production processes or other operations would be the first step to an economically and environmentally sound way of dealing with hazardous wastes. As complete elimination cannot be realized, ways to recycle the wastes should be sought. When reduction or recycling of hazardous wastes prove unsuccessful, treatment of waste will be required and may be done either through incineration or proper storage.

Given that the main sources of air pollution in the cities are the mobile sources, 'the heavy vehicle traffic' hopefully will decrease with improved transportation measures. Monitoring of air quality, including monitoring of the concentrations of lead and carbon monoxide in congested parts of the cities should take place for health and environmental reasons. More and enforced regulation of vehicles and fuel would help reducing these pollutants. Public education regarding solid waste disposal should take place.

To face the problems of possible overdevelopment and the ecological degradation of the Sana'a basin it will be necessary to mark a city border and to restrict housing beyond this line, stop neighborhood planning until the studies on Sana'a future urban development are completed, control unauthorized housing, intensify the development of existing free areas instead of new neighborhoods, and intensify the protection of tree covered areas, wadis, fresh wind lanes and potential recreation areas.

Solutions to urban problems are increasingly being sought at the local rather than the state or national level. These trends underscore the urgent need to build and support the capacity of local governments to manage the environmental and social service problems that accompany rapid urban growth.

\section{Acknowledgments}

The authors acknowledge the contribution of many anonymous persons in this work.

\section{References}

AL ERYANI, M., BA-ISSA A., ALSHWIBI, Y., and BA-BAGI, A (Editors). 1991. Groundwater Pollution in the Sana'a Basin - A preliminary appraisal, Environmental Protection Council, Sana'a. Yemen. 


\section{AHMED M. ALDERWISH and FAYAD A. ALDERWISH}

ALDERWISH, A.M. and DOTTRIDGE, J., 1999. Urban Recharge and its Influence on Groundwater Quality in Sana'a, Yemen. In: Groundwater in the Urban Environment: Selected City Profiles, Volume 21 of the International Contribution to Hydrogeology, eds. Chilton J., A.A. Balkem, Rotterdam, The Netherlands: 85-90.

AL-HAMDI, M., 1994. Groundwater Pollution due to Domestic Waste Water in the Sana'a City Area. MSc. thesis no. EE 138, IHE, Delft, the Netherlands.

ASSOCIATED CONSULTING ENGINEERS, BURNS \& MCDONNELL INTERNATIONAL 1993. Fourth Urban Development Project, Municipal Environmental Component. Phase I, Final R eport. Overview Of Existing Waste Management Systems. MHUP. Yemen.

BROCKERHOFF, M., and BRENNAN, E., 1998. The Poverty of Cities in Developing Regions. Popul Dev Rev; 24: 75-114.

CARL BRO INTERNATIONAL ALS., 1998. Environmental Assessment. Second Review Draft. Sana'a Emergency Power Project. Public Electricity Corporation. ROY.

COHEN, B. 2006. Urbanization in Developing Countries: Current Trends, Future Projections, and Key Challenges for Sustainability. Technology in Society, 28: 63-80

DAR AL-HANDASAH., 1999. Sana'a 1 Environmental Impact Assessment. Sana'a W ater Supply and Sanitation Project. NWSA, ROY.

EDWORTHY, K.J., 1991. Environmental Aspects of Water Management in Northern Yemen. Technical Report. Technical Secretariat of the High Council for Water. UNDP/DTCD Project Yem/88/001.

FOPPEN, J.W., HOOGEVEEN, R., WIESENEKKER, H., ALHAIMY, I and Ali K.Z. 1996. Hydrochemistry of the Sana'a Basin and Microbiology of the Groundwater below Sana'a. SAWAS Technical Report No. 13. TNO/NWSA.

HASKONING ROYAL DUTCH ENGINEERS and ARCHITECTS., 1991. Hazardous Waste in the Republic of Yemen. Technical Final Report. Support to the Secretariat of the Environmental Protection Council. Yemen.

JICA (Japan International Cooperation Agency). 2007. Study For Water Resources Management and Rural Water Supply Improvement. Water Resources Management Action Plan for Sana'a Basin. Draft Final Main Report. National Water Resources Authority, Ministry of Water and Environment. Yemen.

KRUSEMAN, G.P., 1996. Sources for Sana'a Water Supply (SAWAS). Final Technical Report and Executive Summary. NWSA/TNO. Netherlands/Yemen.

NATIONAL RESEARCH COUNCIL., 2003. Cities Transformed: Demographic Change and its Implications In The Developing World. Washington, DC: National Academies Press.

ONIBOKUN, A.G., 1999. Managing the Monster: Urban Waste and Governance in Africa. Ottawa: International Development Research Center.

SATTERTHWAITE, D., 1997. Urban Poverty: Reconsidering its Scale and Nature. IDS Bull; 28: 9-23.

NORRA, 1995, $2^{\text {nd }}$ Ed. Intermediate Work Report, Sana'a Urban Ecology, Follow- up Study. MCHUP/GTZ Planning Assistance for Urban Development.

UNITED NATIONS HUMAN SETTLEMENTS PROGRAMME (UN-HABITAT). 2003. The challenge of slums: global report on human settlements. London: Earthscan.

UNITED NATIONS HUMAN SETTLEMENTS PROGRAMME (UN-HABITAT) 2004/2005. The State of The World's Cities.

ZEUG, G., ECKERT, S., STEINER, U., KUKUK, T., and EHRLICH, D., 2008. Monitoring Urban Growth and its Impact on the Environment: the Case of Sana'a, Yemen. ISDE Conference, 12-14 November, Potsdam.

Received: 25 September 2011

Accepted: 31 December 2011 